\title{
PENGEMBANGAN MODUL IPA TERPADU UNTUK SMP/MTS BERBASIS PROBLEM BASED LEARNING (PBL) DENGAN TEMA FOTOSINTESIS UNTUK MENINGKATKAN KEMAMPUAN BERPIKIR KRITIS
}

\author{
Joko Suparno ${ }^{1}$, Widha Sunarno ${ }^{2}$, Ashadi $^{3}$ \\ ${ }^{1}$ Program Studi Magister Pendidikan Sains FKIP Universitas Sebelas Maret \\ Surakarta, 57216, Indonesia \\ jokosuparno@student.uns.ac.id \\ ${ }^{2}$ Program Studi Magister Pendidikan Sains FKIP Universitas Sebelas Maret \\ Surakarta, 57216, Indonesia \\ widhasunarno@staff.uns.ac.id \\ ${ }^{3}$ Program Studi Magister Pendidikan Sains FKIP Universitas Sebelas Maret \\ Surakarta, 57216, Indonesia \\ ashadi.uns.ac.id@staff.uns.ac.id
}

\begin{abstract}
Abstrak
Penelitian ini bertujuan untuk: (1) mengetahui karakteristik produk modul IPA terpadu yang berbasis PBL dengan tema fotosintesis, (2) mengetahui kelayakan produk modul IPA terpadu berbasis PBL dengan tema fotosintesis, (3) mengetahui peningkatan kemampuan berpikir kritis siswa setelah menggunakan modul IPA terpadu berbasis PBL dengan tema fotosintesis. Penelitian ini merupakan Research and Development (R\&D). Pengembangan dilakukan dengan mengacu pada model 4-D dengan tahapan Define, Design, Develop, dan Disseminate yang dikemukakan oleh Thiagarajan. Pengembangan modul ini dinilai berdasarkan kelayakan isi, penyajian, dan bahasa oleh dosen, guru, dan peer review. Berdasarkan validasi kelayakan isi, penyajian, dan bahasa modul kemudian diujicobakan kecil pada 9 siswa. Setelah direvisi, modul diujicobakan ke kelas. Kemampuan berpikir kritis siswa dianalisis dengan uji nonparametrik dua sampel berhubungan dengan uji Wilcoxon menggunakan software PASW Statistic 18. Hasil penelitian ini adalah (1) modul IPA terpadu berbasis masalah dengan tema fotosintesis dikembangkan menggunakan komponen pembelajaran berbasis masalah dengan menggunakan model 4-D meliputi Define, Design, Develop, dan Disseminate, (2) kelayakan modul IPA terpadu berbasis masalah dengan tema fotosintesis yang dikembangkan berkategori baik berdasarkan penilaian dari ahli, praktisi, dan respon siswa, dan (3) kemampuan berpikir kritis siswa setelah mengikuti proses pembelajaran menggunakan modul IPA terpadu berbasis masalah dengan tema fotosintesis mengalami peningkatan (sig.0,000). Besarnya peningkatan dilihat dari gain score pada 4 aspek kemampuan berpikir kritis meliputi aspek kelancaran 0,43 (sedang), aspek keluwesan 0,30 (sedang), aspek keaslian 0.35 (sedang), dan aspek memperinci 0,33 (sedang).
\end{abstract}

Kata kunci: pengembangan modul, modul ipa terpadu berbasis masalah, kemampuan berpikir kritis, fotosintesis

\section{Pendahuluan}

Ilmu Pengetahuan Alam berkaitan dengan upaya memahami berbagai fenomena alam secara sistematik. Hakekat pembelajaran IPA memiliki empat dimensi yaitu sikap, proses, produk, dan aplikasi. Sikap berkaitan dengan rasa ingin tahu tentang benda, fenomena alam, makhluk hidup, serta hubungan sebab akibat yang menimbulkan masalah baru yang dapat dipecahkan melalui prosedur yang benar. Proses berkaitan dengan prosedur 
pemecahan masalah dengan menggunakan metode ilmiah yang meliputi merumuskan hipotesis, merancang dan melaksanakan penyelidikan, mengumpulkan dan menganalisis data, serta menarik kesimpulan. Produk IPA meliputi, prinsip, hukum, dan teori. Aplikasi berkaitan dengan penerapan metode ilmiah dan produk IPA dalam kehidupan sehari-hari. Keempat dimensi di atas merupakan ciri IPA yang utuh yang tidak dapat dipisahkan satu sama lain. Pembelajaran IPA bukan hanya untuk menguasai sejumlah pengetahuan sebagai produk IPA, tetapi juga harus menyediakan ruang yang cukup untuk tumbuh berkembangnya sikap ilmiah, berlatih proses pemecahan masalah, dan penerapan IPA dalam kehidupan nyata. Pembelajaran IPA yang diterapkan guru dilapangan saat ini cenderung siswa hanya mempelajari IPA sebagai produk, menghafal konsep, prinsip, hukum, dan teori. Keadaan ini diperparah oleh pembelajaran yang berorentasi pada tes/ujian. Akibatnya IPA sebagai sikap, proses, dan aplikasi tidak muncul dalam pembelajaran, hal ini disinyalir menjadi penyebab rendahnya pendidikan di Indonesia.

Berdasarkan Peraturan Menteri Pendidikan Nasional nomor 22 tahun 2006 tentang Standar Isi dan Permendiknas nomor 23 tahun 2006 tentang standar Kompetensi Lulusan, Ilmu Pengetahuan Alam (IPA) merupakan salah satu mata pelajaran dalam muatan kurikulum di SMP. Mata Pelajaran IPA mempelajari tentang fenomena alam yang berkaitan dengan makhluk hidup dan lingkungan sekitar yang bersifat biotik dan abiotik. Mata pelajaran IPA termasuk salah satu mata pelajaran yang menjadi mata pelajaran ujian nasional pada saat ini, sehingga dalam pembelajarannya diperlukan perhatian khusus dengan tanpa mengabaikan mata pelajaran lainnya.
Pembelajaran IPA menurut Puskur (2009) menyatakan bahwa hakikat IPA meliputi empat unsur utama yaitu sikap, proses, produk, dan aplikasi. Trianto (2012) menyatakan keempat unsur itu merupakan ciri IPA utuh yang sebenarnya tidak dapat dipisahkan satu sama lain. Keempat unsur dari hakikat IPA tersebut diharapkan muncul dalam pembelajaran IPA sehingga siswa dapat memperoleh proses pembelajaran secara utuh, memahami gejala alam melalui kegiatan pemecahan masalah dalam menemukan fakta. Untuk mengakomodasi hal tersebut maka dalam IPA kita mengenal beberapa metode dan pendekatan untuk membelajarkan IPA secara utuh dalam proses belajar mengajar. Sesuai dengan karakteristik mata pelajaran IPA, salah satu desain yang dapat diterapkan adalah pembelajaran Problem Based Learning (PBL) atau sering disebut pembelajaran berbasis masalah, selanjutnya disebut PBL. Menurut Arends (2008), esensi PBL berupa menyuguhkan berbagai situasi bermasalah yang autentik dan bermakna kepada siswa, yang dapat berfungsi sebagai batu loncatan untuk investigasi dan penyelidikan. Secara tidak langsung PBL bertujuan untuk membantu siswa untuk mengembangkan keterampilan berpikir dan keterampilan mengatasi masalah, mempelajari peran orang dewasa dan menjadi pelajar yang mandiri (Arends, 2008: 43).

Rendahnya kualitas pendidikan sains di Indonesia di antaranya terlihat dari hasil survei yang dilakukan oleh PISA (Programme for International Student Assessment) pada tahun 2012. Dari total 65 negara dan wilayah yang masuk survei PISA, Indonesia berada di urutan 64 untuk bidang sains, hanya lebih tinggi satu peringkat dari Peru.Survei PISA diikuti oleh negara-negara yang tergabung dalam The Organisation for Economic Co-operation and Development (OECD). PISA menguji kemampuan siswa di tiga bidang yaitu 
matematika, membaca, dan sains. PISA 2012, diikuti oleh lebih dari 510.000 siswa usia 15 tahun di 65 negara dan wilayah. Peraturan Menteri Pendidikan dan Kebudayaan Republik Indonesia Nomor 65 Tahun 2013 Tentang Standar Proses diharapkan, proses pembelajaran pada satuan pendidikan diselenggarakan secara interaktif, inspiratif, menyenangkan, menantang, memotivasi peserta didik, untuk berpartisipasi aktif, serta memberi ruang yang cukup bagi prakarsa, kreativitas, dan kemandirian sesuai dengan bakat, minat, dan perkembangan fisik serta psikologis peserta didik. Prinsip pembelajaran kurikulum 2013 yang digunakan sebagai berikut: 1) Peserta didik diberitahu menuju peserta didik mencari tahu; 2) Guru menjadi satu-satunya sumber belajar menjadi belajar berbasis aneka sumber belajar; 3) Pembelajaran yang menekankan jawaban tunggal menuju pembelajaran dengan jawaban yang kebenaranya multi demensi; 4) Pembelajaran verbalisme menuju ketrampilan aplikatif; 5) Peningkatan dan keseimbangan antara ketrampilan fisikal dan ketrampilan mental; 6) Pembelajaran yang berlangsung di rumah, di sekolah, dan di masyarakat; 7) Pembelajaran yang menerapkan nilai-nilai dengan memberi keteladanan (ing ngarso sung tulodo), membangun kemauan ( ing madyo mangun karso), dan mengembangkan kreativitas peserta didik dalam proses pembelajaran ( tut wuri handayani).

Kurikulum 2013 khususnya untuk tingkat SMP terdapat perubahan pada pembelajaran IPA, pembelajaran IPA dibelajarkan secara terpadu (integrative scence). Pembelajaran terpadu memiliki kelebihan sebagai berikut: 1) Pengalaman dan kegiatan belajar anak relevan dengan tingkat perkembanganya; 2) Kegiatan yang dipilih sesuai dengan minat dan kebutuhan anak; 3) Kegiatan belajar bermakna bagi anak, sehingga hasilnya dapat bertahan lama; 4) Ketrampilan berpikir anak berkembang dalam proses pembelajaran terpadu; 5) Kegiatan belajar mengajar bersifat pragmatis sesuai lingkungan anak; 6) Ketrampilan sosial anak berkembang dalam proses pembelajaran terpadu. Ketrampilan sosial anak diantaranya kerja sama, komunikasi, dan mau mendengarkan pendapat orang lain. Selain mempunyai sifat luwes, pembelajaran terpadu memberikan hasil yang dapat berkembang sesuai dengan minat dan kebutuhan anak. (Depdiknas,2006:2).

Hasil observasi di SMP Negeri 1 Mondokan, Desa Kedawung, Kecamatan Mondokan, Kabupaten Sragen menunjukkan bahwa pembelajaran IPA selama ini masih didominasi dengan metode ceramah, pembelajaran cenderung berpusat pada guru, siswa hanya menghafal konsep-konsep, belum memberikan peluang untuk mengembangkan kemampuan berpikir pada siswa. Bahan ajar siswa berupa buku teks dan belum ada bahan ajar yang dapat mengakomodasi berbagai tingkat dan kecepatan belajar siswa. Belum ada bahan ajar untuk siswa yang berupa modul yang dapat digunakan siswa belajar secara mandiri. Pembelajaran IPA masih dibelajarkan terpisah ilmu fisika, ilmu biologi, ilmu kimia dibelajarkan sendiri-sendiri belum menjadi satu keterpaduan. Kemampuan kognitif siswa masih rendah terlihat dari hasil Ujian Nasional tahun 2014/2015 untuk mata pelajaran IPA dari sejumlah siswa 225 rata-rata nilai 5,52 nilai tertinggi 9,25 nilai terendah 3,0.

Modul merupakan salah satu media pembelajaran yang dapat digunakan peserta didik sebagai sumber belajar. Sistem pengajaran modul merupakan metode pengajaran individual yang menggabungkan keuntungankeuntungan dari berbagai pengajaran individual lainnya seperti tujuan instruksional khusus, belajar menurut kecepatan masing-masing. Modul yang baik tidak hanya menarik tetapi juga 
harus bisa merangsang rasa ingin tahu peserta didik terhadap ilmu yang dipelajari. Apabila peserta didik memiliki rasa ingin tahu yang tinggi terhadap materi pembelajaran, maka peserta didik akan lebih termotivasi untuk belajar. Dewasa ini masih banyak peserta didik menggunakan modul konvensional berupa buku. Modul konvensional tersebut bukan merupakan modul yang buruk, tetapi kebanyakan belum berupa modul IPA terpadu. Bahan ajar siswa yang berupa modul sangat diperlukan dalam pembelajaran IPA. Diberlakukannya kurikulum 2013 di SMP, pembelajaran IPA dibelajarkan dengan IPA terpadu, sehingga kebutuhan bahan ajar terutama modul IPA terpadu sangat diperlukan.

Sungkono (2003) menyatakan bahwa salah satu kompetensi yang perlu dimiliki seorang guru dalam melaksanakan tugasnya adalah mengembangkan bahan ajar. Pengembangan bahan ajar ini penting agar pembelajaran yang dilakukan menjadi lebih efektif, efisien, dan sesuai dengan kompetensi yang ingin dicapai. Carin \& Sund (1985) "Science is the system of knowing about the universe through data collected by observation and controlled experimentation". Sains adalah sebuah sistem pengetahuan tentang alam semesta melalui kumpulan data dari observasi atau eksperimen. Dalam belajar IPA peserta didik diarahkan untuk membandingkan hasil prediksi peserta didik dengan teori melalui eksperimen dengan menggunakan metode ilmiah. Pendidikan IPA di sekolah diharapkan dapat menjadi wahana bagi peserta didik untuk mempelajari diri sendiri dan alam sekitarnya, serta prospek pengembangan lebih lanjut dalam menerapkannya dalam kehidupan sehari-hari, yang didasarkan pada metode ilmiah. Pembelajaran IPA menekankan pada pengalaman langsung untuk mengembangkan kompetensi agar peserta didik mampu memahami alam sekitar melalui proses mencari tahu dan berbuat, hal ini akan membantu peserta didik untuk memperoleh pemahaman yang lebih mendalam.

Bahan ajar untuk siswa yang berupa modul pembelajaran yang sesuai dengan karakteristik peserta didik, lingkungan sosial, budaya, dan geografis, di SMP Negeri 1 Mondokan belum ada. Untuk mengatasi permasalahan tersebut perlu dibuat modul IPA terpadu yang disusun dan dikembangkan dirancang agar menarik minat belajar siswa dan memuat pembelajaran yang mendorong siswa untuk memahami materi yang dipelajari, dengan menghubungkan materi tersebut dengan konteks masalah kehidupan sehari-hari, sehingga siswa memiliki pengetahuan atau ketrampilan yang secara fleksibel dapat diterapkan dari satu permasalahan atau konteks ke permasalahan yang lainnya.

Bahan ajar yang akan dikembangkan berupa modul dengan tema IPA Terpadu yang dipilih adalah fotosintesis. Fotosintesis adalah proses perolehan nutrisi yang dilakukan oleh tumbuhan hijau, tempat berlangsungnya proses tersebut dapat dikaji dari konten biologi. Tumbuhan hijau mendapatkan nutrisi yang dibutuhkan oleh tubuh berupa amilum dan $\mathrm{O}_{2}$ sebagai hasil samping dari air dan $\mathrm{CO}_{2}$. Reaksi pada proses fotosintesis yang mengubah air dan $\mathrm{CO}_{2}$ menjadi amilum dan $\mathrm{O}_{2}$ merupakan reaksi kimia yang dapat dipelajari dan konten kimia. Proses fotosintesis tersebut tidak akan berlangsung jika tidak terdapat cahaya matahari. Peran cahaya matahari yang sangat penting pada proses fotosintesis dapat ditinjau dari konten fisika. Berdasarkan gambaran tersebut, ternyata tema fotosintesis dapat dihubungkan dengan struktur dan fungsi jaringan tumbuhan, reaksi kimia, dan cahaya.

Melalui tema, siswa lebih tertarik terhadap materi yang akan dipelajari. Penyampaian materi dapat lebih mendalam dengan keterpaduan antara 
materi biologi, materi fisika, dan materi kimia. Keterpaduan materi dalam modul ini diharapkan siswa dapat memahami dan memecahkan masalah dalam kehidupan sehari-hari yang berkaitan dengan materi dapat dikuasai dengan baik. Tema pembuatan tahu merupakan tema yang berhubungan dengan aktivitas kehidupan siswa sehari-hari. Siswa dapat memahami materi yang dipelajari, dengan mengaitkan materi tersebut dengan konteks kehidupan sehari-hari, sehingga siswa memiliki pengetahuan atau ketrampilan yang secara fleksibel dapat diterapkan dari satu permasalahan atau konteks ke permasalahan yang lainnya dan membuat pembelajaran menjadi lebih bermakna. Siswa dapat memahami dan menguasai materi dengan baik.

Berdasarkan latar belakang masalah, pengembangan bahan ajar IPA secara terpadu yang disusun berdasarkan analisis kebutuhan bahan ajar pada tema fotosintesis sangat dibutuhkan untuk meningkatkan kemampuan berpikir kritis siswa secara mandiri melalui kegiatan problem based learning (PBL). Bentuk bahan ajar yang dipilih adalah modul IPA Terpadu berbasis problem based learning (PBL). Menurut paparan tersebut, maka perlu diadakan penelitian pengembangan dengan judul sebagai berikut: "Pengembangan modul IPA Terpadu untuk SMP/MTs berbasis Problem Based Learning (PBL) pada tema fotosintesis untuk meningkatkan kemampuan berpikir kritis."

\section{Metode Penelitian}

Model pengembangan yang dipakai adalah model Four-D yang dikembangkan oleh Thiagarajan (1974). Pemilihan model Four-D dikarenakan dalam proses pengembangan modul ini memerlukan beberapa kali pengujian dan revisi sehingga meskipun prosedur pengembangan dipersingkat namun di dalamnya sudah mencakup proses pengujian dan revisi sehingga produk yang dikembangkan telah memenuhi kriteria produk yang baik dan teruji secara empiris. Thiagarajan di dalam Khoirun N dan Endang S (2013: 83) bahwa model Four-D terdiri dari empat tahapan yaitu: 1. Pendefinisian atau define, 2. Perancangan atau design, 3. Pengembangan atau develop, 4. Penyebarluasan atau disseminate.

Subyek uji coba pengembangan ini meliputi: (1) Dosen ahli media, materi, bahasa, praktisi pendidikan, (2) Uji coba kelompok kecil meliputi 10 siswa di SMP Negeri 1 Mondokan, (3) Uji coba kelompok besar meliputi 38 siswa di SMP Negeri 1 Mondokan.

Jenis data yang diperoleh berupa data kuantitatif dan kualitatif. Data kuantitatif diperoleh dari lembar observasi kemampuan berpikir kritis siswa, lembar validasi ahli media, materi, bahasa, praktisi pendidikan serta siswa yaitu nilai rata-rata lembar observasi dalam penilaian aspek kemampuan berpikir kritis siswa dan uji evaluasi dari aspek kelayakan isi, bahasa, gambar, penyajian, dan kegrafisan.

Keefektifan modul dalam pembelajaran dianalisis untuk mengetahui keefektifan modul dalam pembelajaran menggunakan gain score dinormalisasikan untuk postes kelas eksperimen dan kelas kontrol. Gain score dinormalisasikan $(\langle\mathrm{g}\rangle)$ merupakan indikator yang baik untuk menunjukkan keefektifan dalam pembelajaran.

Analisis data untuk menguji perbedaan skor kemampuan berpikir kritis kelas yang menggunakan modul dan tidak menggunakan modul menggunakan uji Kolmogorov-Smirnov ${ }^{\mathrm{a}}$. Penggunaan statistik uji-t memerlukan prasyarat yang harus dipenuhi yaitu normalitas dan homogenitas.

Uji normalitas terhadap postes kelas eksperimen dan kelas kontrol dilakukan dengan uji Wilcoxon menggunakan program SPSS 18,0 dengan taraf signifikansi 0,05 . Uji 
homogenitas dilakukan untuk melihat data berasal dari variansi yang sama atau tidak. Uji ini menggunakan statistik uji homogenitas dengan bantuan SPSS statistic versi 18 dengan taraf signifikansi 0,05 .

Untuk data kualitatif diperoleh saran, catatan, dan komentar sebagai pertimbangan dalam melakukan revisi terhadap modul.

Instrumen pengumpulan data yang digunakan dalam penelitian ini adalah lembar validasi, lembar observasi, tes awal kemampuan berpikir kritis, angket, dan dokumentasi.

\section{Hasil Penelitian dan Pembahasan}

Penelitian ini menghasilkan produk berupa modul IPA terpadu berbasis masalah untuk menigkatkan kemampuan berpikir kritis dengan tema fotosintesis. Data yang diperoleh melewati tahap pengembangan sebagai berikut:

\section{Tahap Pendefinisian}

Kegiatan pra penelitian yang pertama dilakukan yaitu menuyusun scenario pengembangan dan spesifikasi produk yang dikembangkan. Kedua menyusun kisi-kisi angket untuk menganalisa kebutuhan untuk guru, siswa, dan menyusun lembar observasi sumber daya sekolah serta inventarisasi sumber belajar. Ketiga menyusun angket pengungkap kebutuhan guru dan siswa. Keempat menyusun pertanyaan wawancara kepada guru IPA. Keenam mengimplementasikan angket untuk menganalisis kebutuhan untuk guru IPA dan siswa dan menyerahkan lembar pertanyaan wawancara kepada guru IPA dan siswa.

Hasil dari tahap pra penelitian yaitu analisis kebutuhan dari guru IPA dan siswa, analisis sumber daya sekolah dan inventarisasi sumber belajar, analisis siswa, kurikulum dan materi dijadikan dasar untuk mengembangkan modul IPA terpadu berbasis masalah pada materi fotosintesis.

\section{Tahap Perancangan}

Pemilihan format disesuaikan dengan format criteria modul yang diadaptasi dari pendapat Vembriarto yang disusun berdasarkan komponen pembelajaran berbasis masalah dan dimodifikasi peneliti dengan menambahkan tes kemampuan berpikir kritis. Modifikasi ini bertujuan untuk meningkatkan kemampuan berpikir kritis.

Pada tahap desain awal modul yang dikembangkan dilakukan penyusunan modul yang akan menghasilkan draf modul I, II, dam III yang di dalamnya mencakup: (1) cover; (2) peta kedudukan modul; (3) pendahuluan; (4) kegiatan belajar; (5) evaluasi; (6) glosarium; (7) kunci evaluasi. Modul dikembangkan melalui tiga tahap yaitu perancangan, pengumpulan bahan dan materi, dan penyusunan.

Draf I modul IPA terpadu berbasis masalah pada materi fotosintesis terdiri dari tiga modul. Satu modul mewakili satu KD. Selain modul, disusun silabus, RPP, dan kisi-kisi kemampuan berpikir kritis untuk mendukung proses pembelajaran.

\section{Tahap Pengembangan Produk} Awal dan Uji Validitas Pakar

Berdasarkan validasi ahli diperoleh rata-rata 60,5 untuk aspek kelayakan isi sedangkan aspek penyajian 35,0. Hal tersebut menunjukkan bahwa secara keseluruhan modul pembelajaran sudah dalam kategori "Baik".

Berdasarkan validasi praktisi/guru diperoleh rata-rata 33,5 untuk aspek desain dan keterbacaan, sedangkan validasi Peer Review diperolah rata-rata 38,3 . Hal tersebut menunjukkan bahwa secara keseluruhan modul pembelajaran sudah dalam kategori "Baik".

\section{Hasil Revisi Produk Awal}

Perbaikan modul berdasarkan masukan dan saran dari validator yaitu berkaitan dengan gambar disesuaikan 
dengan keadaan yang sebenarnya. Tugas proyek disajikan untuk menghasilkan karya dari siswa. Pada modul diberi tambahan icon untuk aspek kemampuan berpikir kritis agar berbeda dengan icon untuk sintaks berbasis masalah. Gunakan bahasa yang sederhana, tetapi tetap kalimat efektif.

\section{Uji Coba Terbatas dan Revisi II}

Hasil akhir penilaian terhadap modul IPA terpadu berbasis masalah pada tema fotosintesis pada uji coba terbatas memenuhi kriteria baik. Siswa uji coba terbatas memberikan masukan dan catatan melalui angket yang selanjutnya menjadi bahan pertimbangan untuk melakukan revisi II.

\section{Hasil Uji Coba Lapangan dan Revisi III}

Tahap uji lapangan dianalisis sebagai bahan revisi III dan menghasilkan modul IPA Terpadu berbasis masalah, untuk meningkatkan kemampuan berpikir kritis hasil pengembangan. Sampel pada uji lapangan adalah 38 siswa kelas VIIA di SMP Negeri 1 Mondokan. Penilaian kemampuan berpikir kritis diperoleh dari nilai pretest dan postest.

Pembelajaran dilakukan dengan menerapkan modul pada kelas eksperimen dan tidak menerapkan modul pada kelas kontrol. Pada kelas eksperimen siswa melaksanakan kegiatan pembelajaran berbasis masalah yang terdapat di dalam modul untuk meningkatkan kemampuan berpikir kritis.

Analisis untuk mengetahui keefektifan modul dalam pembelajaran menggunakan gain score dinormalisasikan untuk postes kelas eksperimen dan kelas kontrol. Berdasarkan perhitungan $\mathrm{N}$-gain score kelas uji lapangan didapatkan sebesar 0,35 yang menunjukkan katagori sedang. Hal ini membuktikan bahwa penggunaan modul IPA Terpadu berbasis masalah dapat meningkatkan kemampuan berpikir kritis. Untuk hasil $N$-gain score tiap aspek kemampuan berpikir kritis dapat dilihat pada tabel 1

Tabel 1 Hasil $N$-Gain Score Tiap Aspek Kemampuan Berpikir Kritis

\begin{tabular}{lll}
\hline \multicolumn{1}{c}{ N-Gain } & Kategori & \multicolumn{1}{c}{ Aspek } \\
\cline { 3 - 3 } & & $\begin{array}{c}\text { Kelancaran Keluwesan Keaslian Memperinci } \\
\text { (Fluency) (Flexibility) (Originality)(Elaboration) }\end{array}$ \\
\hline $0,7<\mathrm{g}<$ & Tinggi & \\
1 & & \\
\hline $0,3 \leq \mathrm{g} \leq$ & Sedang & $0,430,300,350,33$ \\
0,7 & & \\
\hline $0<\mathrm{g}<$ & Rendah & \\
0,3 & & Rata-rata $=0,35$ (Sedang) \\
\hline
\end{tabular}

Hasil perhitungan $N$-gain score tiap aspek kemampuan berpikir kritis menunjukkan bahwa semua aspek kemampuan berpikir kritis yang ingin ditingkatkan memiliki katagori sedang. Perolehan $\mathrm{N}$-gain score terendah terjadi pada aspek keluwesan (Flexibility) 0,30. Perolehan $N$-gain score tertinggi terjadi pada aspek kelancaran (Fluency).

Analisis data untuk mengetahui perbedaan skor kemampuan berpikir kritis pada kelas eksperimen dan kelas kontrol menggunakan uji prasyarat uji normalitas dan uji homogenitas.

Berdasarkan hasil pada Kolmogorov-Smirnov ${ }^{\text {a }}$ untuk nilai pretest diperoleh signifikansi 0,181 yang berarti nilai signifikansinya lebih dari 0,05 sehingga Ho diterima, kesimpulannya nilai pretest berdistribusi normal. Nilai posttest diperolah signifikansi 0,200 yang berarti nilai signifikansinya lebih dari 0,05 sehingga Ho diterima, kesimpulannya nilai posttest berdistribusi normal.

Berdasarkan uji Levene Statistic, didapatkan signifikansi 0,000 yang berarti nilai signifikansinya kurang dari 0,05 sehingga Ho ditolak, kesimpulannya variansi data tidak homogen. Data pretest dan posttest yang telah diketahui berdistribusi normal dan tidak homogeny. Uji selanjutnya yaitu 
uji Wilcoxon untuk dua kelompok dependent atau berpasangan pada data pretest dan posttest.

Berdasarkan uji Wilcoxon yang telah dilakukan diperoleh Asymp. Sig. (2-tailed) dibawah 0,05 yaitu 0,000 , maka Ho ditolak. Hal ini berarti ada perbedaan kemampuan berpikir kritis siswa sebelum dan sesudah menggunakan modul IPA Terpadu berbasis masalah pada materi fotosintesis yang dikembangkan.

\section{Kesimpulan dan Rekomendasi}

Berdasarkan kajian teori, data hasil penelitian, dan pembahasan dapat disimpulkan bahwa: 1) Modul pembelajaran IPA terpadu berbasis masalah pada materi fotosintesis dikembangkan berdasarkan komponen pembelajaran berbasis masalah dengan format kriteria modul yang diadaptasi dari pendapat Vembriarto dan merujuk pada standar yang telah ditetapkan BSNP tentang standar pengembangan modul dan buku teks pelajaran. Model pengembangan modul pembelajaran IPA terpadu berbasis masalah pada materi fotosintesis menggunakan model 4-D meliputi define, design, develop, and disseminate. Berdasarkan angket pengungkap kebutuhan guru dan siswa serta hasil observasi sumber daya sekolah dan inventarisasi sumber belajar pada tahap define, disusunlah draf modul IPA terpadu berbasis masalah pada materi fotosintesis (design). Tahap selanjutnya yaitu develop, draf modul divalidasi oleh dosen, guru, dan peer review, diujicobakan kecil kepada 10 siswa, dan diimplementasikan di kelas. Tahap disseminate, modul IPA terpadu berbasis masalah pada materi fotosintesis disebarkan ke 5 guru IPA terpadu di kabupaten Sragen. 2) Modul pembelajaran IPA terpadu berbasis masalah pada materi fotosintesis di validasi oleh dosen, guru, dan peer review. Hasil validasi dosen pada kelayakan isi dan kelayakan penyajian menunjukkan kategori baik (rata-rata skor 35). Hasil validasi guru pada kelayakan bahasa menunjukkan kategori baik (rata-rata skor 33,5). Hasil validasi peer review pada kelayakan bahasa menunjukkan kategori sangat baik (ratarata skor 38,3). Berdasarkan hasil validasi dosen, guru, dan peer review menunjukkan bahwa modul pembelajaran IPA terpadu berbasis masalah pada materi fotosintesis layak digunakan untuk meningkatkan kemampuan berpikir kritis siswa. 3) Modul IPA terpadu berbasis masalah pada materi fotosintesis dapat meningkatkan kemampuan berpikir kritis siswa (sig. 0,000). Peningkatan setiap aspek kemampuan berpikir kritis pada kategori sedang. Besarnya peningkatan dilihat dari gain score dari 4 aspek kemampuan berpikir kritis yang meliputi aspek kelancaran (fluency) 0,43; keluwesan (flexibility) 0,30; keaslian (originality) 0,$35 ;$ dan memperinci (elaboration) 0,33 ; aspek kelancaran (fluency) mengalami peningkatan yang paling tinggi. Peningkatan kedua pada aspek keaslian (originality), ketiga pada aspek memperinci (elaboration), dan yang keempat aspek keluwesan (flexibility).

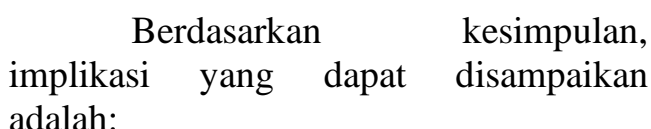

1.Implikasi Teoritik

a. Pembelajaran menggunakan modul IPA terpadu berbasis masalah dapat diterapkan pada tema fotosintesis.

b. Pembelajaran menggunakan modul IPA terpadu berbasis masalah dapat meningkatkan kemampuan berpikir kritis.

2. Implikasi Praktis

a. Model berbasis masalah dapat dijadikan sebagai alternatif pengembangan modul IPA terpadu.

b. Pengembangan bahan ajar perlu menjadi perhatian bagi guru untuk 
mengoptimalkan kemampuan berpikir kritis.

\section{Daftar Pustaka}

Anonim. 2007. Scienci Education Key Learning Area Integrated Science Curriculum and Assessment Guide. HKSARG. 2007.

Asiatun, dkk. 2013. Pengaruh Penerepan Model Pembelajaran Berbasis Masalah Berorientasi Biodiversitas terhadap Aktivitas dan Prestasi Belajar IPA.

E-journal Program Pascasarjana Universitas Pendidikan Ganesha. Prodi Dikdas. 3: 1 -10.

BSNP. 2006. Panduan Penyusunan KTSP Jenjang Pendidikan Dasar dan Menengah. Jakarta.

Cindy E. Hmelo-Silver. 2004. Problem-Based Learning: What and How Do Students Learn? Educational Psychology Review. 16 (3): 235 266.

Depdiknas. 2006. Model Pembelajaran Tematik. Jakarta: Puskur Balitbang Depdiknas.

Dessy Harnaningtyas. 2012. Pengembangan Modul Dasar Penataan Display Pada Mata Pelajaran Penataan dan Peragaan Siswa Kelas XI di SMK Negeri 2 Jepara. Jurnal UNY. Yogyakarta.

Endang Mulyatiningsih. 2011. Metode Penelitian Terapan Bidang Pendidikan. Bandung: Alfabeta.

Erwan Sutarno. 2005. Penerapan Pembelajaran Berbasis Masalah "open-ended" untuk meningkatkan pemahaman konsep dan hasil belajar fisika FPMIPA dasar 1 mahasiswa jurusan Pendidikan fisika FPMIPA IKIP negeri Singaraja, tahun 2005/2006. Jurnal Pendidikan dan Pengajaran IKIP Negeri Singaraja. Edisi Khusus Tahun XXXVIII.

Fogarty, Robin. 1991. The Mindful School: How to Integrate the Curicula.
Palatine, Illionis:IRI/Skylight Publishing, Inc.

Fred Percial \& Henry Ellington. Alih Bahasa. Sudjarwo S. 1984. Teknologi Pendidikan. Penerbit Erlangga. Jakarta.

Gredler, Margaret EB. 1994. Belajar dan Membelajarkan. Raja Grafindo Persada. Jakarta.

Hasibuan JJ. 1988. Prosedur Belajar Mengajar. Remaja Karya. Bandung

Kementerian Pendidikan Nasional. 2011. Panduan Pengembangan Pembelajaran IPA Secara Terpadu. Jakarta.

Lindarti,dkk. 2010. Penerapan Pembelajaran Kooperatif STAD ( Students Teams Achievement Division ) dalam upaya Meningkatkan Hasil Belajar Fisika pada Konsep Optika geometris kelas X SMA. Berkala Fisika Indonesia. 2 (2): 31 - 34.

Martaniah S.M. Kebutuhan Psikologi Anak Remaja, Jurnal Psikologi, Yogyakarta

Moh. Moedjiono. 1992. Strategi Belajar Mengajar. Depdikbud. Jakarta.

Monaghan, JM. 1999. Use of a Computer Simulation to Develop Mental Simulation for Understanding Relative Morion Concepts. Research Report. Int. J. Sei. Educ, Vo1.21. No. 9,921-944

Nasution, S. 1987. Teknologi Pendidikan. Jemmars. Bandung.

Permendiknas nomor 20 tahun 2007 tentang Standar Penilaian Pendidikan. Jakarta.

Poerwadarminta, W.J.S. 1987. Kamus Umum Bahasa Indonesia. Jakarta: Balai Pustaka.

Puskur Balitbang Depdiknas. 2009. Panduan Pengembangan Pembelajaran IPA Terpadu. Jakarta: Depdiknas.

Saifudin Azwar. 2003. Metode Penelitian. Pustaka Pelajar. Yogyakarta. 
Sanapiah Faisal, 1982. Metodologi Penelitian Pendidikan. Usaha Nasional. Surabaya.

Singgih D Gunarso. 1982. Psikologi Perkembangan Seri Pendidikan Keluarga. BPK Gunung Mulia. Jakarta.

Sri Waluyanti, 1998. Efektivitas Paket Video Untuk Mengajarkan Keteramlilam Elektronika. Jurnal Kependidikan Edisi Khusus Dies Natalis. Tahun XXVIII/1998. Lemlit IKIP Yogyakarta.

Steinberg, ER. 1984. Teaching Computers To Teach. Lawrence Erlbaum Associates, Publisher. Hillsdale, New Jersey. London.

Stice James E. 1998. Habits of Highly Effective Teachers. Wellington : Dale Seymor Publication.

Sudjana. 1996. Metoda Statistika. Tarsito. Bandung.

Sukmadinata, NS. 2003. Landasan Psikologi Proses pendidikan. Remaja Rosdakarya. Bandung.

Sumarna S, dkk. 2004. Penilaian Portofolio Implementasi Kurikulum 2004. Remaja Rosdakarya. Bandung.

Sungkono, dkk. (2003). Pengembangan Bahan Ajar. Yogyakarta: FIP UNY.

Suryabrata, Sumadi. 2003. Metode Penelitian. Raja Grafindo Persada. Jakarta.

Suroso AY dkk. 2003. Ensiklopedi Sains dan Kehidupan. Tarity Samudra berlian. Jakarta.

Suryanto. 1999. Matematika Humanistik Sebagai Pembelajaran yang Aktif Efeklif. PPPG Matematika. Yogyakarta

Taylor R. 1980. The Computer In The School. Tutor, Tool, Tutee. Teachers College, Columbia University

Thiagarajan, S; Semmel, D.S; \& Semmel, M.I. $\quad 1974 . \quad$ Instructional Development for Training Teachers of Exceptional Children: A
Sourcebook. Indiana: Indiana University.

Thomas NJ, George AS, and Jay Weinroth. 2002. Development of a Model for Computer Supported Learning Systems. IJET Articles. 3(1)1.

Trianto. 2012. Model Pembelajaran Terpadu. Jakarta: Bumi Aksara.

Wadsworth, Barry J, 1989. Fiaget's Theory of Cognitive and Affective Development. Fourth Edition. Longman, Newyork.

Yusuf Djajadisastra. 1982. Metode Mengajar. Aksara. Bandung

Zainal Arifin. 2012. Evaluasi Pembelajaran. Bandung: Rosda Karya. 
Pembimbing I

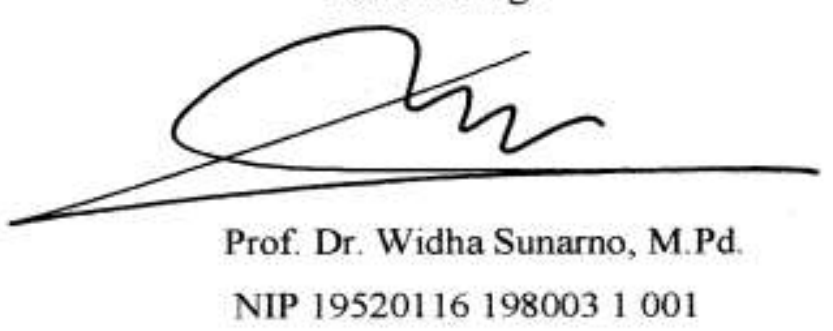

Pembimbing II

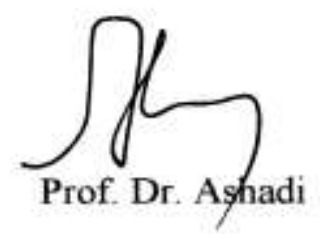

NIP 195101021975011001

Reviewer

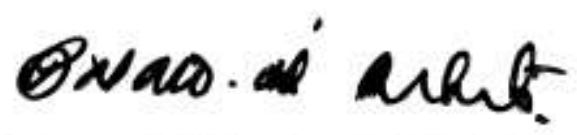

Dr. Baskoro Adi Prayitno, S.Pd., M.Pd.

NIP 197701252008011008 